\title{
A STUDY OF THE LEUKOCYTOSIS PRODUCED IN MAN BY ARTIFICIAL FEVER ${ }^{1}$
}

\author{
By PETER COHEN AND STAFFORD L. WARREN \\ (From the Department of Medicine, Division of Radiology, of the University of \\ Rochester School of Medicine and Dentistry, Rochester, New York)
}

(Received for publication February 14, 1935)

The use of artificial fever in the treatment of various diseases offers an opportunity to observe some of the specific effects brought about in the human body by changes in temperature alone. Variations occurring in the number and kind of cells in the circulating blood may be studied during fever artificially produced by radiant energy with the elimination, in the main, of some of the complicating factors (foreign proteins, toxins, etc.) which may play a part in the spontaneous rises in temperature resulting from acute disease. A knowledge of the peculiar influence of fever upon the white blood corpuscles is important in evaluating the rôle of infection in differential diagnosis, and may change somewhat our concept of a leukocytosis in the presence of a febrile disease. The development of a non-specific leukocytosis with artificial fever emphasizes, perhaps, the retarding mechanism, or negative stimulus, in such diseases as typhoid fever, measles, influenza, etc., which are characterized by a leukopenia.

The method (3) of maintaining the body temperature constantly and accurately at a certain fever level for periods of hours, presents an artificial set-up particularly suitable for study of the effect of fever upon the blood cells. The use of any of the several electrical methods to elevate and maintain the patient's temperature is followed by the same relative changes and does not influence the results. This is borne out in our own clinic with the use of diathermy, radiothermy, and radiant energy, and by the reports of others (2).

In a study of patients treated with the radiotherm, Hinsie and Carpenter (7) found a slight reduction in red blood cell count and hemoglobin during a series of treatments. There was also an increase in polymorphonuclears and a relative decrease in lymphocytes. Hinsie and Blalock (6) reported an increase of about 75 per cent in leukocyte count as a result of artificial fever pro-

1 This work was aided by funds from the Rockefeller Foundation for Medical Research. duced by the radiotherm and carried on for 7 hours by wrapping the patients in blankets. This rise usually reached a maximum at the end of the 9th hour, and regained its normal level at the end of about 20 hours. They found the rise to be less pronounced over a course of 20 treatments. The leukocytosis was characterized by an increase in the percentage of polymorphonuclears at the expense, chiefly, of the lymphocytes. They also found an increase in the non-filamentous forms. Tenney (15) reported similar findings.

In the use of the radiotherm, Bierman and Fishberg (2) found an increase of white blood cells during the period of temperature elevation. The percentage of polymorphonuclears 'was increased and that of the lymphocytes was correspondingly lowered. $\mathrm{He}$ also found an increase in the number of red blood cells, and in many instances a marked increase in the immature forms of red blood cells.

A group of patients, subjected to diathermy, was studied by Perkins (14). All of these patients were suffering from dementia paralytica. The temperature was raised to $105^{\circ} \mathrm{F}$. and then allowed to drop to normal as rapidly as possible. Patients were given ten such treatments, five per week for two weeks. He found a leukocytosis in this group which was not particularly affected by the first few treatments given, but was decidedly increased by the time the entire series of ten treatments had been completed, and this increase persisted for at least three days after the completion of therapy.

In patients treated with balneotherapy, Neymann (13) found an increase in white blood cells, especially of polymorphonuclears, directly after the bath. In patients treated with diathermy, he reported an increase of one million red blood cells per cu. $\mathrm{mm}$. and a slight relative increase of polymorphonuclears and eosinophiles, and a corresponding decrease of small and large monocytes. These values returned to a normal level 24 to 48 hours after treatment.

In all of these studies the body temperature varied considerably over the febrile period.

Bunker (4) reviewed the literature on the parenteral introduction of various protein substances into the organism. Almost always the injection of these substances was followed at a brief interval by a definite leukopenia, which was not infrequently succeeded by a leukocytosis. In patients inoculated with tertian malaria, this observer found that there was a definite reduction in the number of leukocytes in the peripheral blood in 30 out of 33 instances, with a subsequent leukocytosis of somewhat moderate degree in 27 out of 35 . The reduction 
had its onset at about the time of the chill, reaching its maximum during the latter part of the ascent or at the apex of the temperature curve. The maximum degree of leukocytosis usually followed by 2 to 4 hours the time of maximum leukopenia, and appeared near the summit of the temperature curve, or more usually during its gradual descent.

Knudson and Schaible (9), in a study of dogs kept in an ultra-high frequency field, found a considerable increase in the number of red blood cells and the hemoglobin, and a marked increase in immature forms of red cells. There was also a marked increase in the total white blood cells due to an absolute and relative increase in the polymorphonuclears. The lymphocytes and eosinophiles were usually relatively markedly decreased. The changes in monocytes were less marked and less constant. A rather similar change was found by Lawrence, et al. $(8,10)$ following the injection intravenously and intraperitoneally of sodium bicarbonate or ammonium chloride or infection of the peritoneal cavity with $B$. coli or the injection of killed cultures of $B$. coli and diphtheria toxin in the guinea pig. Similar changes have been observed in dog and man. A postoperative neutrophilic leukocytosis was found by the same workers in obstructive jaundice experimentally produced in dogs while the response of the lymphoid series was inconstant.

Murphy and Sturm (11) exposed mice, rats and guinea pigs to dry heat from $55^{\circ}$ to $60^{\circ} \mathrm{C}$. for five minutes, and noted an immediate fall in white blood cells. The polymorphonuclears recovered slowly, and required several weeks to regain the normal number. The lymphocytes rose rapidly after the initial fall, and continued to rise for two or three weeks, often 200 per cent to 300 per cent above normal.

Caillet and Simonds (5) heated mice repeatedly with air at $60^{\circ} \mathrm{C}$. for five minutes at intervals of 10 days. This resulted in a temporary lymphopenia followed by an increasing lymphocytosis up to about the 40th day, or the third or fourth heating. After this time, each successive heating became less and less effective, until after about 200 days, or 12 to 13 heatings, the total leukocyte count and the per cent of lymphocytes returned to, or below, normal and showed little or no effect from further heating. No record of the temperature of the animals is given, and these experiments cannot be compared directly because the animals were totally enclosed in the hot air chamber. In brief, identical changes may be brought about by the circulating blood cells by several methods which do not seem at all related.

\section{METHOD AND MATERIAL}

In order to determine the changes occurring in the number of blood cells during artificial fever treatments, in which the patients' temperature was elevated and maintained at a constant level for a definite period by radiant energy, 10 patients were studied during a total of 11 treatments. There were 7 treatments for the gonococcus infection; one patient in this group was also suffering from latent syphilis and chronic infectious arthritis. The diagnoses in the remaining 4 cases were syphilis of the central nervous system, chronic infectious arthritis, brain tumor, and carcinomatosis. All observations of temperature during treatment were made by means of a resistance thermometer placed in the rectum of the patient.

In the patient suffering from infectious arthritis alone, the rectal temperature was elevated for $4 \frac{1}{2}$ hours at $40.5^{\circ} \mathrm{C}$. There were 9 treatments in which the temperature of the body was raised to $41.5^{\circ} \mathrm{C}$. and $41.6^{\circ} \mathrm{C}$. and maintained between 5 hours and $5 \% 3$ hours, exactly at this temperature. Included in this group were the cases with the gonococcus infection, the case of brain tumor, and that of syphilis of the central nervous system. The body temperature of the patient with carcinomatosis was raised to $41.6^{\circ} \mathrm{C}$. and maintained exactly at that level for 21 hours. All patients were afebrile before and after treatment.

In practically every case the red blood cell count, hemoglobin, white blood cell count, and differential count, including the Schilling hemogram made from cover-slip blood smears stained with Wright's stain were determined before treatment and every hour, starting at that time at which the temperature had reached the desired height, and was being maintained at a constant level. These determinations were continued for several hours after the termination of the fever (during which time the patient's temperature was normal). The blood studies were then followed at intervals until the patient was discharged from the hospital. All of the blood cell counts were done under constant conditions by one of us (P. C.), using the same pipettes, counting chamber, and a calibrated hemoglobin standard (100 per cent equals 13.8 grams hemoglobin per 100 cc.). The counts were made from blood taken from the ear.

\section{RESULTS}

In all but two cases the maximum increase in white blood cells was more than 100 per cent of the original number. In the case of the patient with the lower fever temperature $\left(40.5^{\circ} \mathrm{C}\right.$.) the maximum increase was only 49.1 per cent and 36.6 per cent in one of the patients with the tem- 
perature held at $41.6^{\circ} \mathrm{C}$. for 5 hours. The maximum increase was over 200 per cent in two cases (temperature $41.6^{\circ} \mathrm{C}$. for 5 hours), and reached 315 per cent in the patient with the prolonged fever $\left(41.6^{\circ} \mathrm{C}\right.$. for 21 hours).

The maximum increase in white blood cells appeared at different times, and the time of the drop to the normal figures varied. In three of the cases the maximum increase occurred at the end of the period of fever. These three cases had a fever of $41.6^{\circ} \mathrm{C}$. of 5 hours' duration. In two of the cases the maximum increase occurred at the third hour of the fever. In two more cases the maximum increase was noted 2 hours after the termination of the five-hour fever. The peak of the leukocytosis was noted at the 4th hour of the fever in two cases. In the case with the lower fever $\left(40.5^{\circ} \mathrm{C}\right.$. for $4 \frac{1}{2}$ hours), it appeared one hour after the termination of the fever. In the case in which the higher temperature $\left(41.6^{\circ}\right.$ C.) was maintained for 21 hours, the maximum increase was noted at the 10th hour. In the latter case, blood counts were made at less frequent intervals.

The return to normal or the previous level varied. One case had a white blood corpuscle count below 10,000 per cu. mm. within three hours following the termination of the fever; another within $6 \frac{2}{3}$ hours. The count of the patient with the low fever reverted to normal in 6 hours. In the case of the patient whose maximum increase was only 36.6 per cent, the white blood cell count returned to the pre-treatment level in 2 hours. The original white blood cell count in this case was 11,600 per cu. mm. In six cases the counts were slightly elevated 6 to 8 hours after the treatment was terminated. In five cases the counts were normal by the following day. In one patient it was still slightly elevated. The white blood cell count of the patient who received the very long fever was still markedly elevated the day following the termination of the fever, although the temperature at the time was normal. The cell counts obtained from this patient on the third day were normal.

Along with the increase in the total number of white blood cells, there was a marked relative and absolute increase of polymorphonuclears in all cases. Before treatment there was no case in which the percentage of these cells was above 72 per cent. As a result of the fever, the polymorphonuclears increased in every case, varying from 84 per cent to 93 per cent. Likewise, the total number of the polymorphonuclears increased. Before treatment the maximum number of these cells in any case was 8,400 per cu. $\mathrm{mm}$. The fever caused the total number of these cells to vary between 11,760 and 23,200 per cu. $\mathrm{mm}$.

There was a substantial increase in the relative and absolute numbers of immature forms of polymorphonuclears as a result of the fever in more than half of the cases. The pre-febrile level varied from 0 to 7.5 per cent. In five of the cases, including the patient with the short fever, they remained below 6 per cent, while the rest varied from 12 per cent to 24 per cent during or following the fever treatment.

The decrease in relative and absolute numbers of lymphocytes was as marked as the increase in polymorphonuclears. Before the fever the percentage of lymphocytes varied from 21 per cent to 42 per cent. The low point in lymphocytes in the individual cases varied from 1 per cent to 10 per cent. The fall in absolute numbers was not as great as the difference in percentages might indicate, due to the great increase in the total white blood cell count. However, in practically every case the number of lymphocytes was less than half of the original, and in one case was $1 / 10$ of the original.

There was a tendency for the monocytes to increase, both in absolute and relative numbers. The changes in basophiles and eosinophiles were not significant.

In general, there was only a slight rise in hemoglobin ( 0 to 10 per cent). In two cases, however, it rose to 20 per cent above the level obtained before treatment. One of these was the case treated for 21 hours. There was a corresponding rise in the red blood cell counts. The maximum increase usually appeared toward the end of the treatment, or shortly after the treatment was terminated.

In the blood of the patient treated for 21 hours, normoblasts were found from the 10th hour to the 21 st hour of the fever. One to three such cells were found while 200 white blood cells were being counted. In none of the other patients were normoblasts found. 
Four of the cases are reported in some detail to show the character of the changes noted.

The lowest elevation of temperature studied was in a patient (F. M.), weighing $96 \mathrm{kgm}$., suffering from chronic infectious arthritis of three years' duration, with a normal temperature $\left(36.9^{\circ}\right.$ C. rectal) and an initial white blood cell count of 9,400 per cu. $\mathrm{mm}$. The rectal temperature was elevated to $40.5^{\circ} \mathrm{C}$. by means of radiant energy within 70 minutes and maintained at $40.5^{\circ}$
C. for $4 \frac{1}{2}$ hours by means of radiant energy. The temperature was then lowered (by blowing air upon the patient's skin) in $1 \frac{1}{2}$ hours to $37.0^{\circ}$ C., and after one more hour it remained normal $\left(36.5^{\circ}\right.$ to $36.7^{\circ}$ C. $)$. Complete blood studies were made at hourly intervals between 9:00 a.m. to $8: 40$ p.m., except the last observation during the height of the fever, which interval was extended 30 minutes (11/2-hour interval) to include the end of the febrile period. A complete blood
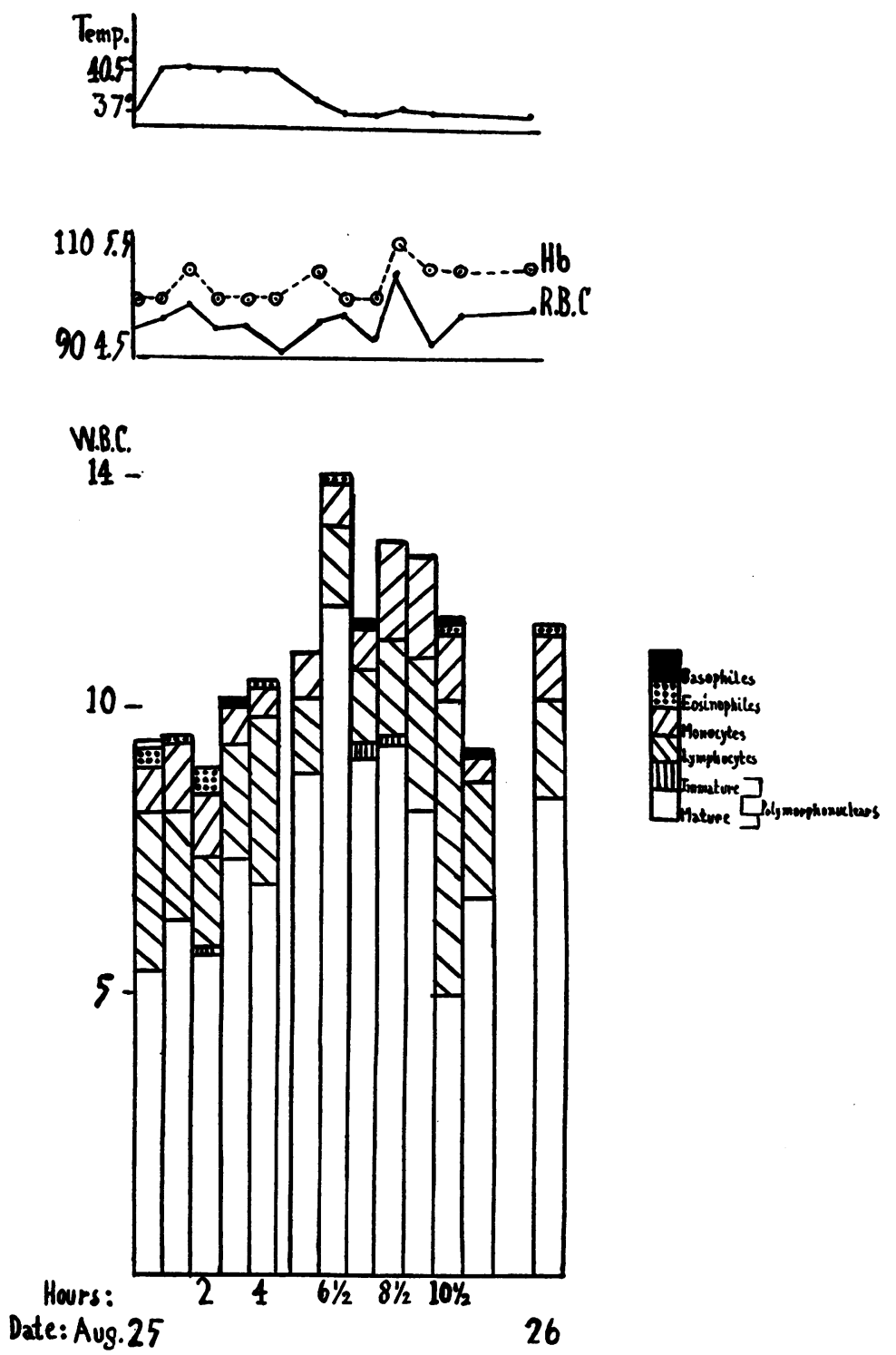

Fig. 1. (F. M.)

Temperature is expressed in ${ }^{\circ}$ C., R.B.C. in millions, $\mathrm{Hb}$ in per cent, and W.B.C. in thousands. 5 hours of fever at $41.5^{\circ} \mathrm{C}$. 
study was done at 9:30 a.m. the following morning. Barbital and chloral hydrate were used for narcosis. The patient was given all the fluids he would drink during and after the treatment. The maximum fluctuation of the hemoglobin was no greater than 10 per cent, and this occurred 4 hours after the end of the febrile period and later than the peak of the leukocytosis. The maximum elevation of white blood cells occurred one hour after the termination of the fever (temperature of $38.0^{\circ} \mathrm{C}$.). The immature polymorphonuclear leukocytes did not increase above the normal percentage during the rise in total white blood cell count to 14,00 per cu. mm. There was a slow steady fall in total white blood cell count after this. The chart and table give the complete data (Figure 1, Table I).

Another patient (M. T.) received two artificial fever treatments of five hours each at $41.6^{\circ} \mathrm{C}$., 16 days apart. This was an 18-year old girl, who was suffering from acute gonorrheal urethritis and salpingitis. The white blood cell count at the time the patient was placed in the radiant energy cabinet for her first treatment was 9,600 per cu. $\mathrm{mm}$. Her rectal temperature was $37.0^{\circ}$ C. A period of 100 minutes elapsed before the patient's temperature reached the desired level. Blood studies were made every hour from this time throughout the febrile period, and for 6 hours following this period. The maximum increase in white blood cell count noted in this case occurred at the $3 \mathrm{~d}$ hour of fever and reached 19,800 per cu. mm. It fell gradually from this time on and when the last count was made that evening it was 11,800 per cu. mm., i.e. slightly elevated, although the temperature then was $36.5^{\circ} \mathrm{C}$. The following morning the white blood cell count was 9,000 per cu. mm. This patient's hemoglobin rose once and only 5 per cent. This increase appeared at the time the temperature reached $41.5^{\circ} \mathrm{C}$., and it remained at the previous level throughout the rest of the period. The mature and immature polymorphonuclears increased in relative and absolute numbers, while the lymphocytes decreased.

TABLE I

Correlation of total number of leukocytes with absolute values before and at the maximum rise.

\begin{tabular}{|c|c|c|c|c|c|c|c|c|c|c|c|c|c|c|c|}
\hline \multirow{2}{*}{ Patient } & \multirow{2}{*}{ Diagnosis } & \multicolumn{2}{|c|}{ Fever } & \multirow{2}{*}{$\begin{array}{l}\text { Initial } \\
\text { W.B.C. }\end{array}$} & \multirow{2}{*}{$\begin{array}{c}\text { Maxi- } \\
\text { mum } \\
\text { W.B.C. }\end{array}$} & \multirow{2}{*}{$\begin{array}{l}\text { Initial } \\
\text { polys. }\end{array}$} & \multirow{2}{*}{$\begin{array}{l}\text { Maxi- } \\
\text { mum } \\
\text { polys. }\end{array}$} & \multirow{2}{*}{$\begin{array}{l}\text { Initial } \\
\text { immaa- } \\
\text { ture } \\
\text { polys. }\end{array}$} & \multirow{2}{*}{$\begin{array}{l}\text { Maxi- } \\
\text { mum } \\
\text { imma- } \\
\text { ture } \\
\text { polys. }\end{array}$} & \multirow{2}{*}{$\begin{array}{l}\text { Initisl } \\
\text { lymph. }\end{array}$} & \multirow{2}{*}{$\begin{array}{c}\text { Mini- } \\
\text { mum } \\
\text { lymph. }\end{array}$} & \multirow{2}{*}{$\underset{\mathrm{Hb}}{\text { Initial }}$} & \multirow{2}{*}{$\underset{\mathbf{H b}}{\text { Maxi- }}$} & \multirow{2}{*}{$\begin{array}{l}\text { Initial } \\
\text { R.B.C. }\end{array}$} & \multirow{2}{*}{$\begin{array}{l}\text { Max- } \\
\text { mum } \\
\text { R.B.C. }\end{array}$} \\
\hline & & $\begin{array}{l}\text { Dur- } \\
\text { ation }\end{array}$ & $\begin{array}{c}\text { Temper- } \\
\text { ature }\end{array}$ & & & & & & & & & & & & \\
\hline F. L... & $\begin{array}{l}\text { Chronic gonococesl } \\
\text { cervicitis and } \\
\text { urethritis. }\end{array}$ & $\begin{array}{c}\text { hours } \\
5\end{array}$ & $\begin{array}{l}{ }^{\circ} C . \\
41.5\end{array}$ & $\begin{array}{c}\text { per } \\
\text { c. } m m . \\
4,650 \\
- \\
\end{array}$ & $\begin{array}{c}\text { per } \\
\text { c. } \operatorname{mm} . \\
14,750\end{array}$ & $\begin{array}{l}\text { per } \\
\text { c. } m m \text {. } \\
2700\end{array}$ & $\begin{array}{c}\text { per } \\
\text { c. mm. } \\
13,720\end{array}$ & $\begin{array}{l}\text { per } \\
\text { c. } m m . \\
93\end{array}$ & $\begin{array}{c}\text { per } \\
\text { c. } m m . \\
717\end{array}$ & $\begin{array}{c}\text { per } \\
\text { c. } m m . \\
1350\end{array}$ & c. $\underset{\mathbf{m m}}{\operatorname{mer}}$. & $\begin{array}{l}\text { per } \\
\text { cent } \\
75\end{array}$ & $\begin{array}{r}\text { per } \\
\text { cent } \\
85\end{array}$ & $\begin{array}{c}\text { millions } \\
3.29\end{array}$ & $\begin{array}{c}\text { millions } \\
3.92\end{array}$ \\
\hline M.T. (2) & $\begin{array}{c}\text { Urethritis and } \\
\text { salpingitis. }\end{array}$ & 5 & 41.6 & 7,000 & 24,000 & 3640 & 18,750 & 70 & 1200 & 2590 & 1288 & 70 & 70 & 3.83 & 4.08 \\
\hline H. LaF.. & $\begin{array}{l}\text { Acute gonococeal } \\
\text { cervicitis, urethritis } \\
\text { and salpingitis. }\end{array}$ & 5 & 41.6 & 7,950 & 22,900 & 5100 & 19,700 & 795 & 5030 & 2550 & 597 & 90 & 100 & 4.10 & 4.89 \\
\hline G. 8.... & \begin{tabular}{|l|} 
Chronic prostatis, \\
urethritis, epidy- \\
dimitis and chronic \\
infectious arthritis.
\end{tabular} & 5.3 & 41.6 & 8,100 & 17,750 & 5751 & 14,863 & 81 & 2076 & 1863 & 334 & 85 & 100 & 4.23 & 5.23 \\
\hline C. A.... & Tabo-paresis. & 5 & 41.6 & 11,600 & 15,850 & 8352 & 13,217 & 232 & 777.5 & 2204 & 622 & 110 & 115 & 5.59 & 5.68 \\
\hline C. T.... & \begin{tabular}{|c} 
Brain tumor, \\
unverified.
\end{tabular} & 5 & 41.6 & 5,100 & 18,950 & 2910 & 17,050 & 0 & 565.5 & 1683 & 758 & 100 & 120 & 4.90 & 5.55 \\
\hline F. M.... & $\begin{array}{l}\text { Chronic infoctious } \\
\text { arthritis. }\end{array}$ & 4.5 & 40.5 & 9,400 & 19,000 & 5452 & 11,760 & 0 & 230 & 2726 & 1400 & 100 & 110 & 4.75 & 5.23 \\
\hline B. W... & Carcinomstosis. & 21 & 41.6 & 4,850 & 20,150 & 2940 & 18,120 & 339.5 & 4640 & 1390 & 898 & 70 & 90 & 3.79 & 4.48 \\
\hline
\end{tabular}


The patient still had gram-negative diplococci in urethral smears and was given a second artificial fever treatment 16 days later. The leukocyte count before the second treatment was 7,000 per cu. $\mathrm{mm}$. ( rectal temperature $37.3^{\circ}$ C.). One hundred minutes elapsed before the temperature reached the desired level $\left(41.5^{\circ} \mathrm{C}\right.$.) and blood counts were made at hourly intervals as in the first treatment. The leukocyte count reached 24,000 per cu. mm., which occurred 2 hours after the fever was terminated. The patient's temperature at this time was $37.6^{\circ} \mathrm{C}$. Seven hours after the termination of the fever the white blood cell count was still elevated, 14,800 per cu. mm., with

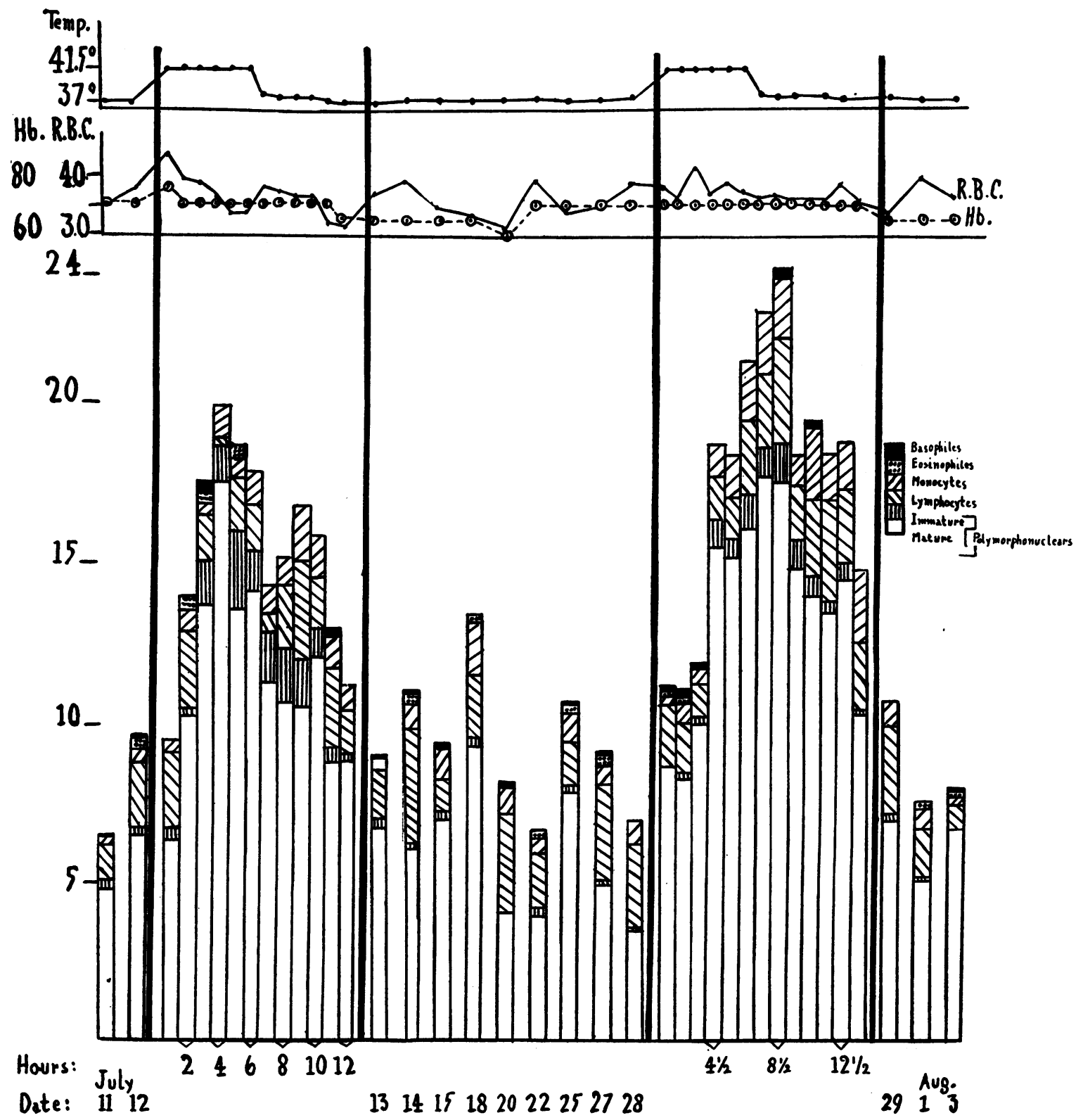

Fig. 2. (M. T.) Two Five-Hour Fevers at $41.5^{\circ}$ C. Ten Days Apart.

Temperature is expressed in ${ }^{\circ} \mathrm{C}$., R.B.C. in millions, $\mathrm{Hb}$ in per cent, and W.B.C. in thousands. The intervals between the longitudinal, heavy lines represent hourly determinations on the days of the fever treatment. See legend of Figure 1. 
a temperature of $37.3^{\circ} \mathrm{C}$. The following morning the white blood cell count was 10,750 per cu. $\mathrm{mm}$. The hemoglobin during this treatment did not vary at all. Similar changes in polymorphonuclears and in lymphocytes were noted as in the first treatment, except that this time the immature polymorphonuclears did not go above 5 per cent of the total white blood cells. However, there was a substantial increase in absolute numbers of these cells. This patient also received barbital and chloral hydrate as a narcotic at the beginning of the treatments (Figure 2, Table II).
The longest fever period in this series was one of 21 hours at $41.6^{\circ}$ C. This patient (B. W.) was suffering from carcinomatosis and this was her fourth fever treatment. She had had one treatment of 6 hours, one of 7 hours, and one of 13 hours at $41.6^{\circ} \mathrm{C}$. in the two month period before this treatment. Barbital, sodium bromide and chloral hydrate were used for narcosis. Her white blood cell count was 4,850 per cu. mm. three days before this long artificial fever treatment was given. During the febrile period blood counts were made at approximately 5 hour

Temp.

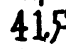

37

H6. R.B.C.

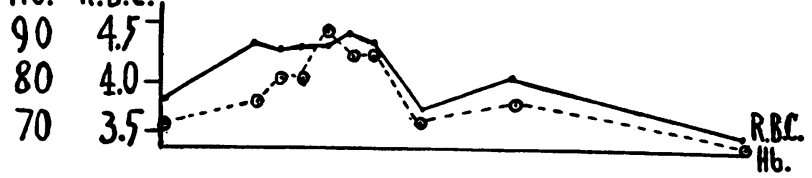

$20-$

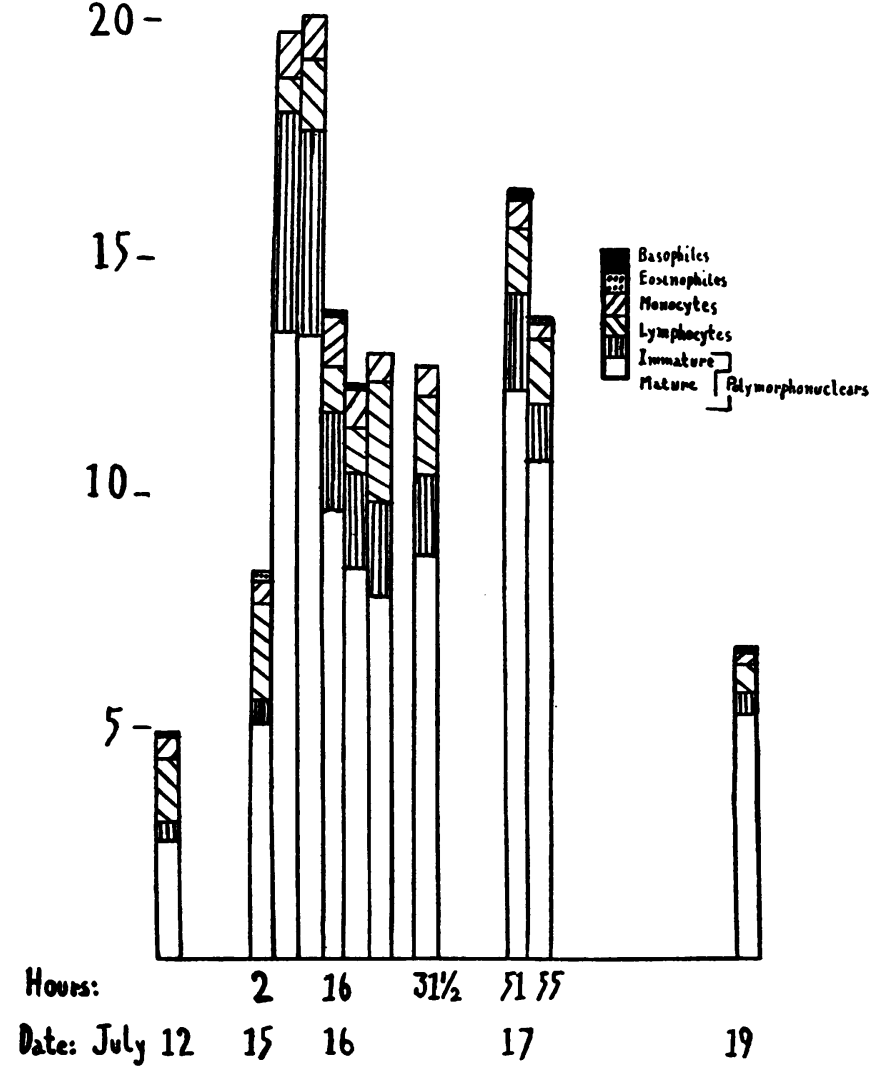

Fig. 3. (B. W.) Twenty-one Hours of Fever at $41.5^{\circ} \mathrm{C}$.

Temperature is expressed in ${ }^{\circ} \mathrm{C}$., R.B.C. in millions, $\mathrm{Hb}$ in per cent, and W.B.C. in thousands. 
intervals. The highest white blood cell count obtained in this case was 20,150 per cu. $\mathrm{mm}$. at the 10th hour of the fever. A leukocytosis of 13,850 per cu. $\mathrm{mm}$. was still present 32 hours following the termination of the fever, although there was no elevation of temperature. The third day following the termination of the fever the count was normal. The absolute and relative increase in mature and immature polymorphonuclears was also noted in this case, as well as the absolute and relative decrease in lymphocytes. The hemoglobin increased 20 per cent. The patient was given all the fluids she would take. The maximum increase in white blood cell count was noted

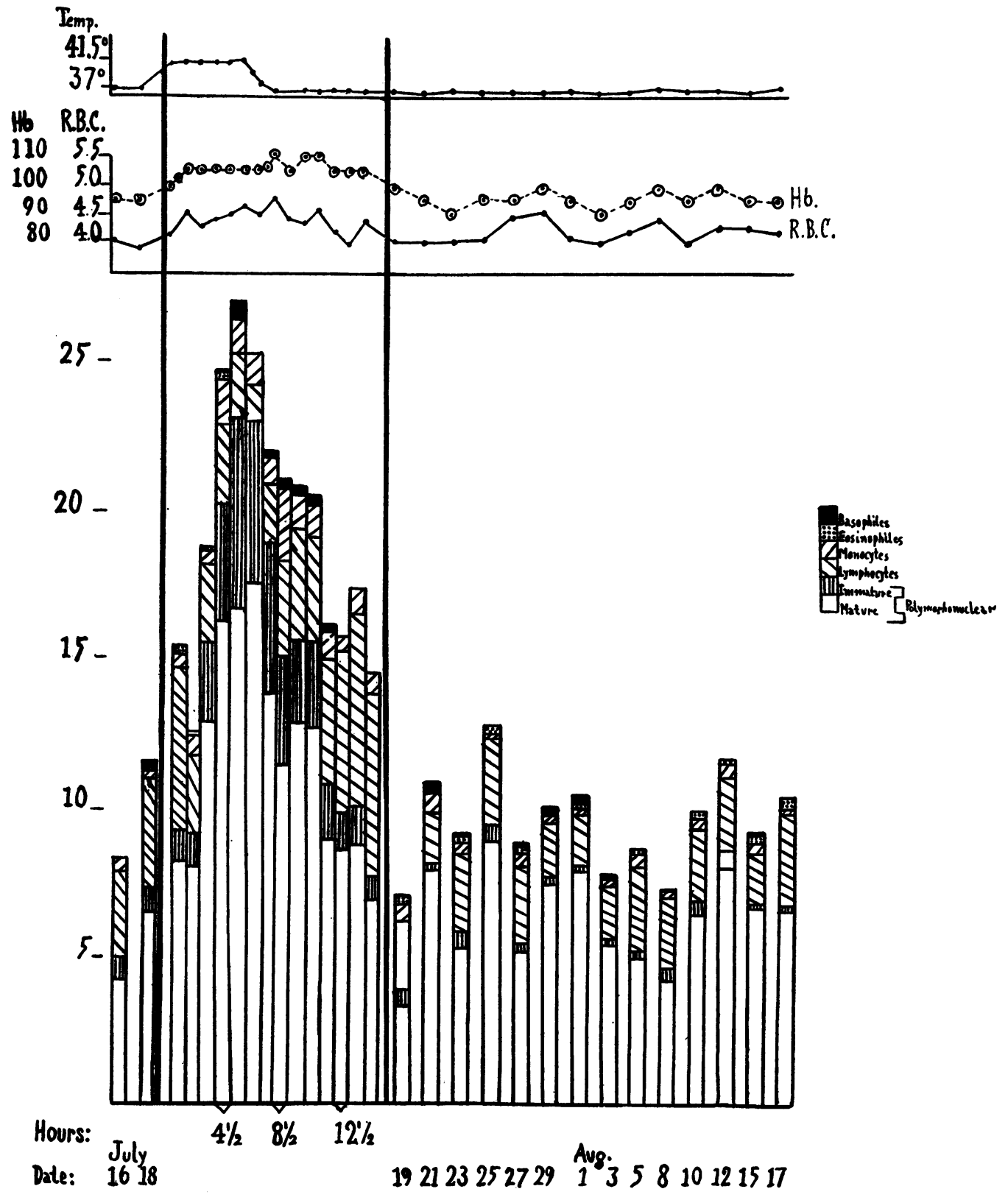

FIG. 4. (B. S.)

Temperature is expressed in ${ }^{\circ} \mathrm{C}$., R.B.C. in millions, $\mathrm{Hb}$ in per cent, and W.B.C. in thousands. The intervals between the longitudinal, heavy lines represent hourly determinations on the day of the fever treatment. 
at the 14th hour. Normoblasts were found in the smear from the 10th to the 21st hour of the fever (Figure 3, Table III).

The greatest leukocytosis occurred in a patient (B. S.) who was suffering from gonorrheal conjunctivitis and gonococcus infection of the lower birth canal. Barbital, sodium bromide and chloral hydrate were used for narcosis. The leukocyte count on the morning of her fever treatment was 11,650 per cu. mm. The rectal temperature was $37.2^{\circ} \mathrm{C}$. at this time. The body temperature was raised to $41.6^{\circ} \mathrm{C}$. in $11 / 2$ hours and maintained at this level for 5 hours. Blood counts were made every hour until the 8 th hour after the fever. The white blood cells increased to a maximum of 27,000 per cu. mm. at the 4 th hour of the treatment. The leukocyte count decreased gradually to 14,600 per cu. $\mathrm{mm}$. at the end of the 8th hour, with a rectal temperature of $36.8^{\circ} \mathrm{C}$., following the treatment. On the following morning the count was 7,100 per cu. mm. The increased relative and absolute numbers of polymorphonuclears were also noted in this case. The immature polymorphonuclears increased from 7 per cent to 24 per cent. There was also a fall in the relative and absolute numbers of lymphocytes during the fever. The hemoglobin was elevated 15 per cent at the 2 nd hour after the treatment. The blood counts in this patient were followed for a month following the treatment, during which time there was no evidence of the gonorrheal infection. There were no marked changes in the counts during this time (Figure 4, Table IV).

Table V summarizes the results in all the cases studied.

\section{DISCUSSION}

Any strict comparison of the individual cases upon the basis of percentage and relative numbers is not possible because of the small series studied, but several general conclusions may be drawn, since our observations are in keeping with the general findings of others who have used other means (radiant energy) for producing artificial fever.

Although the nearly mature polymorphonuclear leukocytes did not increase in every case, it is interesting that these immature cells appeared in large numbers during the peak of the leukocytic response and then decreased as the number of leukocytes decreased.

The fall of from 28.5 per cent to 6.5 per cent in the lymphocytes in the patient receiving the 21 hour fever treatment $\left(41.6^{\circ} \mathrm{C}\right.$.), as well as the fall in lymphocytes in the other cases, cannot be explained. Whether these cells are stored somewhere in the body or take some specific part in attacking the pathological process present or are destroyed by the febrile reaction is not clear. The evidence in the experimental data published (Nakahara) (12) is not sufficient, in our opinion, to warrant the assumption that they are destroyed.

The slight amount of concentration of the blood, as evidenced by the rise in hemoglobin percentage and the red blood cell count, is probably not responsible for the leukocytosis, which is far out of proportion to the increase in hemoglobin, although many complicated factors are involved such as the increased demand for oxygen during the fever. Barbour (1) has stated that blood is first diluted and then concentrated whenever there is a considerable rise in temperature. Every precaution was taken to prevent dehydration and, therefore, concentration of the blood. In some of the patients the maximum increase in hemoglobin percentage occurred after the treatment was finished. At the termination of the treatment, during the 60 to 80 minutes of the cooling-off process, the fluid intake is usually 500 to $1000 \mathrm{cc}$., which would tend to cause dilution rather than concentration of the blood. Later as the body tissues store fluids some such change might be expected though it was not observed. Also, the change in the distribution among the types of the white blood cells is another point against the leukocytosis being a result of the concentration of the blood alone.

This finding, namely, a leukocytosis during a prolonged, maintained artificial fever, suggests that an elevation of the white blood cell count in a patient with a spontaneous fever (due to infection) may in certain cases be an index of the fever rather than of the extent of the infection. A leukocytosis with a low fever, or without fever, may be of greater clinical significance. It should be emphasized that many factors in addition to the fever may be responsible for the leukocytosis; in fact, as suggested by Lawrence et al. (10), tissue autolysates may be the main stimulus. Dur- 
ing fever the production of these may be increased in sites of inflammation. The balance between the circulating and stored mature cells is probably a critical one and one which artificial fever, as well as spontaneous febrile reaction, may readily upset. Upon the subsidence of the fever the balance is rapidly restored to its previous level. Some of the cells of the myeloid and erythrocyte series that are nearly mature are also capable of appearing and disappearing (i.e., being stored as immature cells if they do not mature in the blood) in response to a febrile reaction.

An increase in pulse rate (of 100 to 200 per cent) and presumably an increase in circulation rate might cause the cells to be washed out of storage sites into the circulation, but in some patients the peak of the leukocytosis occurred after the treatment, when the pulse rate, blood pressure and presumably the circulation rate had returned to normal or nearly normal. The appearance of these immature cells would suggest the mobilization of all the available cells (mature and nearly mature, both leukocytes and erythrocytes) into the circulating blood. The increase may represent the total in reserve, or number available, at any given short period of time (hours) and before the stimulus calling them out has had time to activate the maturation or formation of a large number of new cells in the marrow or myeloid structures, such as would occur over a longer period of time from the reaction to an infectious process in the body. There is no evidence pointing to the place of storage of these cells after they are called forth, nor do we need to suppose that they are destroyed after the supposed need for them is past.

The patients studied were as nearly normal as any of those receiving treatment in our clinic, and the constancy of the reaction would seem to indicate that the qualitative nature of the changes observed are significant of the changes brought about primarily by the elevation of the temperature. As suggested above, however, the destruction of tissue in the pathological conditions treated may influence the situation somewhat; in this connection it is notable that the case of acute gonorrheal infection showed the greatest leukocytosis.

The number and kinds of observations may seem few, but they represent all that the individual patient would tolerate during the treat- ment by artificial fever. In the stage of semidelirium at $41.5^{\circ} \mathrm{C}$. the patients may be upset easily by any slight irritation. In some patients it was very difficult at times to obtain accurately filled pipettes because of the antagonism of the patients to the procedure, making it necessary to repeat this procedure many times.

\section{SUMMARY}

1. The cytological variations in the blood resulting from prolonged artificial fever, produced by radiant energy, were studied in 10 afebrile patients (only one with acute disease) during a total of eleven treatments.

2. A leukocytosis was found in every case. The maximum change, the onset, duration and the extent of this change, in relation to the fever period varied from patient to patient.

3. A relative and absolute increase of polymorphonuclear leukocytes was observed during, or immediately following, the febrile period.

4. There was a substantial relative and absolute increase in immature polymorphonuclear leukocytes in 6 of the 11 cases.

5. There was a relative and absolute decrease in lymphocytes in all cases.

6. There was a slight rise in the red blood cell count and hemoglobin during or immediately following the period of fever. Immature red blood cells were found in a single case, which also exhibited the greatest increase (20 per cent) in hemoglobin (during a fever of $41.6^{\circ} \mathrm{C}$. for 21 hours.

7. These observations suggest a mobilization into the circulation of available and nearly mature cells of the myeloid and erythrocytic series as a result of the fever, while the cells of the lymphoid series decrease (storage ?) during this period.

\section{BIBLIOGRAPHY}

1. Barbour, H. G., The heat regulating mechanism of the body. Physiol. Rev., 1921, 1, 295.

2. Bierman, W., and Fishberg, Ella H., Some physiologic changes during hyperpyrexia induced by physical means. J. A. M. A., 1934, 103, 1354.

3. Bishop, F. W., Horton, C. B., and Warren, S. L., A clinical study of artificial hyperthermia induced by high frequency currents. Am. J. M. Sc., 1932, 184, 515.

4. Bunker, H. A., Jr., Serial hourly leukocyte counts in tertian malaria, as observed in malaria-treated 
general paralytics. Am. J. M. Sc., 1926, 172, 681.

5. Caillet, O. R., and Simonds, J. P., Repeated exposure to high temperature; effect on lymphoid tissue and on leukocyte count. Arch. Path., 1929, 8,622 .

6. Hinsie, L. E., and Blalock, J. R., Leucocytes in general paralysis treated by radiothermy. Psychiat. Quart, 1931, 5, 432.

7. Hinsie, L. E., and Carpenter, C. M., Radiothermic treatment of general paralysis. Psychiat. Quart., 1931, 5, 215.

8. Lawrence, J. S., and Josey, A. I., Studies in the physiology of the eosinophil. II. The effect of subcutaneous and intraperitoneal injections of $B$. coli on the white blood cells of the guinea-pig. III. The effect of the intraperitoneal injection of ammonium chloride on the white blood cells of the guinea-pig. IV. The effect of intraperitoneal and intravenous injections of sodium bicarbonate solution on the white blood cell picture. Folia Haematologica, 1932, 48, 313, 323, 330.

9. Knudson, A., and Schaible, P. J., The effect of exposure to an ultra-high frequency field on growth and on reproduction in the white rat. Arch. Path., 1931, 11, 723.

10. Lawrence, J. S., Huffman, M. M., Jones, E., Maddock, S. J., and Nowak, S. J. G., Variations in the number of white blood cells associated with experimental obstructive jaundice. Arch. Path., 1930, 9, 683.

11. Murphy, J. B., and Sturm, E., Effect of dry heat on the blood count in animals. III. Studies on lymphoid activity. J. Exper. Med., 1919, 29, 1.

12. Nakahara, W., The source of the lymphocytosis induced by means of heat. J. Exper. Med., 1919, $29,17$.

13. Neymann, C. A., Principles and Practice of Physical Therapy. In "Hyperpyrexia Produced by Physical Agents." Vol. 1, Chap. 17. Pemberton and Coulter, Hagerstown, Md., 1933.

14. Perkins, C. T., Hyperthermia in dementia paralytica. I. (a) Blood chemistry studies (concluded). II. Studies on the blood count. Arch. Phys. Therapy, 1933, 14, 461.

15. Tenney, C. F., Artificial fever produced by short wave radio and its therapeutic application. Ann. Int. Med., 1932, 6, 456. 